\title{
Comparative genome analyses highlight transposon-mediated genome expansion shapes the evolutionary architecture of 3D genomic folding in cotton
}

Article

Keywords:

Posted Date: December 11th, 2020

DOI: https://doi.org/10.21203/rs.3.rs-93594/v2

License: (1) This work is licensed under a Creative Commons Attribution 4.0 International License. Read Full License

Version of Record: A version of this preprint was published at Molecular Biology and Evolution on May 11th, 2021. See the published version at https://doi.org/10.1093/molbev/msab128. 


\section{Abstract}

The authors have requested that this preprint be withdrawn due to erroneous posting.

\section{Full Text}

The authors have withdrawn this preprint from Research Square. 